\title{
SKILLED LABOUR DEMAND IN THE MALAYSIAN CONSTRUCTION SECTOR
}

\author{
NOORASIAH SULAIMAN*, RAHMAH ISMAIL, NASIR SAUKANI AND BAWANI \\ LELCHUMANAN
}

Center of Sustainable and Inclusive Development Studies, Faculty of Economics and Management, the National University of Malaysia, Selangor, 43600 Bangi, Selangor, Malaysia.

*Corresponding author: rasiahs@ukm.edu.my

Submitted final draft: 26 August $2020 \quad$ Accepted: 27 August 2020

http://doi.org/10.46754/jssm.2021.06.018

\begin{abstract}
Acquiring a skilled workforce is one of the major challenges the Malaysian construction sector is facing. As the construction industry in Malaysia relies on labour, shortage of labour will hamper the industry's sustainability. By focusing on demand for high-skilled labour, i.e. professional and technical workers, this study analyses the construction sector's demand for labour according to skills in the short and long runs, and specifically the labour demand of the construction subsectors, particularly the residential building, non-residential building, civil engineering and specialised construction activities subsectors. Furthermore, using the elasticity of labour-output, labour workforce for these two categories are estimated for the years 2015 and 2020. This study uses the Malaysia Construction Industry Survey data from 1990 to 2012 of four subsectors, namely residential buildings, non-residential buildings, civil engineering and specialised construction activities. The findings show that both categories of labour demand have a relationship with its determinant in the short and long runs. However, the supply for professional workers is still lacking, and this shortage is addressed by substitution with technical workers. The need for manpower is higher for technical workers. In addition, the manpower required in 2015 and 2020 are the largest for specialised construction activities due to its larger initial stock and higher output growth.
\end{abstract}

Keywords: Skilled labour demand, labour demand elasticity, manpower estimates, sustainability of the construction sector.

\section{Introduction}

Skilled labour shortage is among the greatest challenges facing Malaysia's construction sector. As the construction industry in Malaysia relies on labour, shortage of labour has become a major constraint that could possibly inhibit this industry from growth and being sustainable. One of the reasons for this is that the construction sector is among the most labour-intensive industry, despite the fact that this industry actually deals with capital and new technologies. Furthermore, according to one of the objectives of the Sustainable Development Goals (SDGs), construction projects must be designed for socio-economic benefits, and take into consideration its impact on the world's ecosystem and environment. Skills development are necessary for sustainable development to be achieved (McGrath \& Powell, 2016). For instance, pathways to a low-carbon economy are often seen as a technical issue that requires engineering knowledge and skills (McKinsey and Company 2009).

Malaysia's construction sector expands by increasing the demand for residential and commercial buildings. Under mega projects that are planned specifically for infrastructural development, various ongoing projects, such as urban transportation systems, ports and airports, highways, power plants, sewerage systems, water dams and water networks, are involved (CIDB, 2017). However, due to the nature of this sector, which relies on labour (MPC, 2017), it is estimated that one million construction workers are needed per annum to mobilise infrastructure and building projects as a lot of tasks needed to be done manually (Manap et al., 2017). Therefore, acquiring skilled labour is quite a challenge for the economy, especially the construction sector. The construction sector is continuously facing a severe shortage of labour, 
particularly skilled local labour (Najib et al., 2019; Ahmad Zaki et al., 2012). As reported by the Construction Industry Development Board (CIDB, 2018), there is a significant declining trend in skilled workers and a similar trend is reported in general construction workers (unskilled worker) as well.

Change in demand for labour deals with two significant types of transition in economic structures. Firstly, growth in a sector or an industry, and secondly, when the sector grows, there are transformations in the employment structure and composition of a particular sector or industry (Bhorat et al., 2013; Vendrik \& Corvers, 2009; Wilson, 1994). At the firm level, demand for labour principally depends on the wage rate. An increase in wages will lower the demand for labour (Borjas, 2004). In addition, the reach in the output target is dependent on the labour workforce availability, which should be in line with industry requirements. The demand for skilled workforce has increased, as well as the types of jobs that match the professional and technical aspects, both in developed and developing countries (William, 2004). William (2004) said there are four reasons for the relative demand for high-level labour workforce, which are (i) the complementary relationship between labour and capital; (ii) the dynamic change in technology; (iii) changes in the job structure and trade which attribute to economic openness and competitiveness; and, (iv) foreign investment.

Moreover, rapid globalisation and industrial revolution led to changes in the demand for labour, skill and knowledge implementation. More skilled and educated workers will increase the returns on physical capital investment, as both parts complement each other ( $\mathrm{O}^{\text {' }}$ Connor \& Lunati, 1999). This highlights the capital-skill complementarity, which indicates that high-skilled worker are needed for the implementation of technology. In this respect, more skilled workers are needed to deal with advanced technology. Globalisation has had a huge impact on the economic structures of many countries. The capital flow of foreign direct investment from developed countries to less developed countries has led to an increase in the capital-output ratio, thereby increasing the need for skilled and educated workers (Mayer, 2000).

Prior studies reveal that labour substitutability is possible among different types of labour, except for unskilled and skilled labour (Behar, 2010; Kreuser \& Rankin, 2017). In line with theory, demand for unskilled and skilled workers is imperfect substitution (complementary). Shortage of one category of labour will affect the employment and productivity levels of the other (Arnold \& Shah, 2019). For the category of skilled labour, this involves labour with similar or homogeneous skills, in which they are able to serve and take place the positions of one another (Constant, 2014). This implies that the relative wages of different types of skilled labour will be determined not only by demand for a particular skill, but also by demand for other types of skilled labour (Kreuser \& Rankin, 2017). Therefore, the relative rise in wage rates for a particular skilled worker will reduce the demand for themselves and increase the demand for upper skilled labour.

The higher the skilled possessed by the labour, the lower the elasticity of substitution, which means that the substitution between skilled and unskilled labour is imperfect and it is unlikely to switch between these two types of labor (Mollick, 2011). It would be much more difficult to replace skilled workers with unskilled workers as capital intensity (i.e. human capital and other related capital such as technology) possession belongs to skilled workers. This argument is supported by the Malaysian construction sector, which is experiencing labour shortages for both skilled and unskilled labour, having to increasingly rely especially on illegal foreign labor from neighbouring countries (Arnold \& Shah, 2019). With extensive link in terms of backward and forward linkages, the Malaysian construction sector provides huge support to the domestic economy and generates a large number of employments for the economy.

The growth and sustainability of construction industries worldwide are 
substantially dependent on a skilled and productive labour workforce (Chang-Richards et al., 2017). The percentage of skilled labour in Malaysia is about $25.5 \%$ of the total workforce (MoF, 2018). Shortage of labour is a sign that the demand for labour in a particular labour market exceeds the supply, and it is pertinent in the case of Malaysia's construction sector (Najib et al., 2019). The rapid growth experienced by this sector in the past few decades has caused a large increase in the labour workforce (Ismail et al., 2017). Hence, lack of labour is becoming crucial issue for the construction sector, including the challenge to retain skilled workers and the poor participation of local workers. Without sufficient labour, specifically skilled labour, many development projects will be completed later than the expected date, and moreover, the growth of the construction sector will be slower.

Another remaining issue is the sector's over-reliance on foreign workers to fill in the gap caused by the shortage of low-skilled labour as this category of job is shunned by locals as it is dirty, dangerous and difficult, or " $3 \mathrm{D}$ ". In addition, the industry is burdened with the issues of hiring foreign workers, mainly in obtaining foreign workers through the proper channels and training them, thus increasing cost of hiring. The persistent issue of skilled labor shortage and the undeniable fact that skilled labour is important for construction industries worldwide, including in Malaysia, are the prime motivation for this study.

A study on labour demand revolves around its basic determinants, which are output, capital and price, often referred to as wage rate. A number of studies on labour demand have been conducted (Lelchumanan et al., 2019; Sulaiman et al., 2016; Ismail et al, 2012 \& 2017; Chung et al., 2010; Wong et al., 2007; Wong et al., 2008; Saens et al., 2008; Falk and Koebel, 2000). Initial determinant variable (output and wage rate) and other variables, comprising labour productivity, price of goods and interest rates, are observed to have a positive relationship with labour demand (Saens et al., 2008; Wong et al., 2007). However, Akintoye and Skitmore (1994) found that factors that influence demand for labour consists of unemployment rate, price of inputs, real interest rate, profit and the economic environment. Concentrating on the construction sector, Wong et al. (2008) identified that cost is relatively dominant compared with other variables (degree of project difficulties and type of projects).

Falk and Koebel (2000), who studied the demand for labour according to occupational types, indicated that the labour demand for all occupational categories is inelastic in the short and long runs. The study, which also observed demand for labour according to skill levels, found that unskilled labour are relatively more elastic compared with medium- and high-skilled labour in the short run. In another study, Ismail et al. (2012) distinguished the demand for highskilled labour based on the occupational types. Both occupational categories, managerial and professional, and supervisory and technical workers, were shown to have output levels that are positively and significantly influenced by the demand for labour.

The objective of this study is to examine labour demand for the construction sector according to skills in the short and long runs. The next objective is to analyse the demand for labour according to the four construction subsectors, namely residential buildings, nonresidential buildings, civil engineering and specialised construction activities. The final objective is to forecast the labour workforce of skilled workers in the construction sector. This study fills the gap by contributing to the literature in terms of demand for labour, specifically skilled labour in the construction sector. Next, this study contributes to discussions on the elasticity of labour substitution between professional and technical labour. Finally, realising that this sector is experiencing a shortage of skilled labour, estimating the need for labour for these two types of skilled labour is important. If these two types of skilled labour are homogeneous, they are assumed to be substitutable. This might give the construction sector in Malaysia an advantage in resolving the problem of shortage of high-skilled labour, that is managerial and professional labour, at least 
in the short run. However, to make high-skilled labour available, a systematic plan conducted by the construction sector is needed to eventually solve the persistent issue of skilled labour shortage and retaining them.

The rest of this paper is set up as follows. The second section of this paper provides an overview of the growth and contributions of Malaysia's construction sector. The third section deliberates on the methodology, data sources and model estimation. The fourth section presents the result and discussion, and finally, section five presents the conclusion.

\section{An Overview of Malaysia's Construction Sector}

Over the last six decades, the construction sector has played an important role in Malaysia's economic transformation policies from an agricultural nation to manufacturing and services nation. The sector's position more significant in the Industrial Revolution 4.0 and the Shared Prosperity Vision 2030. This sector is strongly related to other economic sectors, and remains significant in influencing and shaping the overall Malaysian prospect in economic growth and development. In line with SDG objectives, the sustainability of the Malaysian construction sector is vital and can be retained with priority given to skilled labour. The construction sector's contribution to Malaysia's gross domestic product (GDP) is predicted to be positive for the years ahead despite the continuing declining trend. This sector's contribution to GDP in the first quarter of 2020 is at $4.5 \%$, the lowest among the 5 main economic sector in Malaysia (DSM, 2020). The services sector remains the biggest contributor to GDP, with a share of $58.4 \%$, followed by manufacturing (22.3\%), mining (7.3\%), and agriculture (6.5\%) (DSM, 2020).

Malaysia's construction sector is forecasted to grow by $10.3 \%$ and expected to contribute $5.5 \%$ to the economic growth per annum until 2020 (Malaysia, 2015). The civil engineering subsector is supposed to continue as the key sector drive for the construction sector. This is mainly supported by the implementation of the federal government's infrastructure development mega projects, such as the Mass Rapid Transit (MRT) Sungai Buloh-SerdangPutrajaya (SSP) Line, the Light Rail Transit Line 3 in Klang Valley, and the Pan Borneo Highway in East Malaysia (Sabah and Sarawak) (MoF, 2019). The civil engineering subsector remained dominant as the main contributor to the value of construction work done, with a share of $44.9 \%$ in the first quarter of 2020 . The residential building subsector is the second largest prominent subsector with contribution of $25.9 \%$, followed by non-residential building subsector $(24.1 \%)$ and specialised construction activities (5.0\%) (DoSM, 2020).

With extensive backward and forward linkages with other economic sectors, the construction sector provides huge employment opportunities for locals and foreigners. The labour workforce expanded from 14.7 million in 2016 to 15.0 million in 2017, with almost 14.5 million people being employed in 2017, compared with 14.2 million in 2016 (MoF, 2018; 2019; CIDB, 2018). It shows that a total of 300,000 jobs were created in the economy. Furthermore, the labour force participation rate has risen from $67.7 \%$ in 2016 to $68.0 \%$ in 2017 , with unemployment being considered steady at $3.4 \%$.

A detailed look into the employment numbers of the construction sector shows that this sector employed approximately 1.3 million people in 2017 , contributing $9.2 \%$ of the total employment (14.5 million) in Malaysia. The civil engineering subsector registered the highest number of employment, with 349,765 people, or $26.3 \%$, in 2017 . The second highest contributor was the non-residential building subsector at 337,838 people $(25.4 \%)$, followed by the residential building subsector $(331,851$ people, or $24.9 \%$ ) and the specialised construction activities subsector $(310,812$ people, or $23.4 \%$ ). The construction sector also recorded the highest productivity growth of $12.4 \%$ in 2016 compared with other economic sectors. The mining and quarrying, agricultural, 
manufacturing and services sectors registered productivity increases of $11.3 \%, 3.4 \%, 1.4 \%$ and $2.8 \%$, respectively (DoSM, 2019).

The sustainability of the global construction industries, including in Malaysia, is highly dependent on skilled workforce to mobilise and enhance the productivity in line with the latest technology adoption and utilisation (ChangRichards et al., 2017). However, currently, Malaysia's construction sector still relies on labour (both skilled and unskilled), and most tasks are labour-intensive (MPC, 2017: Manap et al., 2017). Therefore, one million construction workers are estimated to be needed every year to position the infrastructure and building development projects. Although Malaysia recorded a low unemployment rate at $3.4 \%$, the undisputable fact is that the country, specifically the construction sector, continues to fight to acquire skilled labour for the construction sector. As a domestic investment sector, this sector faces a prolonged severe shortage of labour, specifically local skilled workers (Najib et al., 2019; Ahmad Zaki et al., 2012).

Thenumber of construction workers declined by $21.0 \%$ in 2017 , from 767,563 people in 2016 to 606,256 (CIDB, 2018). The remarkable drop of construction workers happened in all skill levels, except project managers, which increased by $13.8 \%$, from 59,698 workers in 2016 to 67,963 in 2017. Skilled construction workers also registered a similar trend and declined by $30.3 \%$, from 94,714 workers in 2016 to 66,024 in 2017 (CIDB, 2018). Meanwhile, general construction workers (with a nature of unskilled workers) had a decline of $18 \%$ to 370,703 , compared to 452,054 workers in 2016 (CIDB, 2018). The declining trends of skilled labour are worrisome and need to be address urgently for the sustainability of this sector in Malaysia.

\section{Data and Methodology}

\section{Source of Data}

Data on the construction sector is obtained from the Department of Statistics Malaysia, which is conducted for the Survey of Construction Industry. The data utilised covers a 23-year period from 1990 to 2012 . The four subsectors involved are residential buildings, nonresidential buildings, civil engineering, and specialised construction activities ${ }^{1}$. The data is prepared at the two digit level of industrial classification based on the Malaysian Standard Industrial Classification (MSIC 2000 and 2008). The year 2005 is used as base year to deflate the data of wages and outputs variables. Furthermore, labour is categorised according to occupational type based on the Malaysia Standard Classification of Occupations (MASCO, 2008). As this study focuses only on the skilled labour category, the high level category contains the occupational type of managerial and professional workers. Meanwhile, the next category involves workers of technical and associated professional occupational types, hereinafter referred to as technical workers and professional workers, respectively.

\section{The Methodology}

This study employs regression using autoregressive distributed lag (ARDL) and seemingly unrelated regression (SUR). The ARDL model is considered a dynamic labour demand model because it enables the short- and long-run analysis to be taken into account. The regression of SUR enables this study to look into the specific results of each subsector analysis. Finally, using the elasticity of demand of both types of skilled worker, this study continues with the estimation of labour workforce required in the construction industry's four subsectors. The size of the labour workforce are estimated for the years 2015 and 2020 .

1 The specialised construction activities (special trades) include demolition and site preparation; electrical, plumbing and other construction installation activities; building completion and finishing; and, other specialised construction activities. 


\section{Autoregressive Distributed Lag (ARDL) - A Dynamic Labour Demand Model}

From the theoretical perspective, we assume that labour will be demanded when firms produce output, i.e. goods. Based on the concept, demand for labour arises based on the Cobb Douglas production function. The general equation of production function using these three variables as output and two inputs can be written as:

$$
Q_{t}=A K_{t}^{\alpha} L_{P t}^{\beta} L_{T t}^{\delta}
$$

Where is the output level and $A$ is the parameter depicting the level of technology used in the production process. Variables $K, L_{p}$ and $L_{T}$ are the value of capital stock, the number of professional labour and the number of technical labour, respectively. While $\alpha, \beta$ and $\delta$ are the parameters to be estimated, and $t$ is year. The total cost spent in a production process can be written as follows:

$$
C_{t}=r K_{t}+w_{P t} L_{P t}+w_{T t} L_{T t}
$$

Where $C$ is the total cost, and $r w_{p}, w_{T}$ are the price of capital stock, and the professional and technical labour, respectively. Firms or industries are assumed to reduce the total cost subject to the output level produced. Therefore, applying the Lagrange multiplier function, the production and cost can be expressed as written in equation (3).

$$
\begin{aligned}
\mathcal{L}= & r K_{t}+w_{P t} L_{P t}+w_{T t} L_{T t}+ \\
& \lambda\left\{Q_{t}-A K_{t}^{\alpha} L_{P t}^{\beta} L_{T t}^{\delta}\right\}
\end{aligned}
$$

We then differentiate equation (3) with respect to the inputs and output to derive the function of each input used in this study, respectively. By doing that, we find the functions of capital $(K)$ and labour demand, respectively. Equations (5) and (6) represent the functions of labour demand for each labour category, professional, and technical, respectively.

$$
\begin{aligned}
& K_{t}=f\left(w_{P}, w_{T}, r, Q\right) \\
& L_{P t}=f\left(w_{P}, w_{T}, r, Q\right) \\
& L_{T t}=f\left(w_{P}, w_{T}, r, Q\right)
\end{aligned}
$$

$$
L_{T t}=f\left(w_{P}, w_{T}, r, Q\right)
$$

The dynamic labour demand function demonstrates the analysis of short- and long-run period. In the short run, demand for labour is exhibited from the change in the firm's output level attributed to the change in labour demand, which resulted from the change in wage on the production costs. Moreover, for the long run, change in demand for labour is ascribed to the substitution effect due to the relative wage rate of labour. Thus, firms respond to a wage reduction by substituting the relatively lower-cost labour in their production process. Therefore, the long-run labour demand curve will be more elastic than the short-run curve due to the substitutability effects of labour, where the elasticity of labour demand in response to a wage change will be larger than the short run.

Based on prior studies, the elasticity of labour demand can vary according to various factors, including industries heterogeneity, type of skills, type of occupational groups, wages rate and age cohort. Past studies found that elasticity of labour demand differs by age cohorts (Kim \& Hewings, 2018; Manuel \& Julian, 2018), industry-levels (Adam \& Moutos, 2014), and differences in wage (Devesh, 2019). A study by Luis et al. (2019) reveals that heterogeneity in labour demand elasticity is found among industries across regions, sectors, and plant sizes (depending on workers' skills). The elasticity of labour demand also differs according to different components of weather (Rajapaksha, 2018).

From the analysis, we also expect that the elasticity for each group of labour demand (professional and technical) can be different. This is supported by prior studies that pointed out that labour within skilled types are rather similar and they can relieve each other (Kreuser and Rankin, 2017); Constant, 2014); Behar, 2010). As a result, the higher wages for professional workers, the greater demand for technical labour (Mollick, 2011).

Based on equations (5) and (6), the dynamic labour demand for both professional and technical groups are applied in the ARDL model as shown in equations (7) and (8). 


$$
\begin{aligned}
& \Delta \operatorname{LnProf}_{i t}=\alpha_{0}+\beta_{11} \text { LnProf }_{i, t-1}+\beta_{21} \text { LnOutp }_{i, t-1}+\beta_{31} \text { LnWagepro }_{i, t-1} \\
& +\beta_{41} \text { LnWagetec }_{i, t-1}+\sum_{j=1}^{p-1} \gamma_{11 j} \Delta \text { LnProf }_{i, t-j} \sum_{j=0}^{q-1} \gamma_{21 j} \Delta \text { LnOutp }_{i, t-j} \\
& +\sum_{j=0}^{q-1} \gamma_{31 j} \Delta \text { LnWagepro }_{i, t-j}+\sum_{j=0}^{q-1} \gamma_{41 j} \Delta \text { LnWagetec }{ }_{i, t-j}+\varepsilon_{1 t} \\
& \Delta \text { LnTech }_{i t}=\alpha_{1}+\beta_{21} \text { LnTech }_{i, t-1}+\beta_{22} \text { LnOutp }_{i, t-1}+\beta_{32} \text { LnWagepro }_{i, t-1} \\
& +\beta_{42} \text { LnWagetec }_{i, t-1}+\sum_{j=1}^{p-1} \gamma_{21 j} \Delta \text { LnTech }_{i, t-j} \sum_{j=0}^{q-1} \gamma_{22 j} \Delta \text { LnOutp } p_{i, t-j} \\
& +\sum_{j=0}^{q-1} \gamma_{32 j} \Delta \text { LnWagepro }_{i, t-j}+\sum_{j=0}^{q-1} \gamma_{42 j} \Delta \text { LnWagetec }_{i, t-j}+\varepsilon_{2 t}
\end{aligned}
$$

Where $\Delta$ LnProf is the change in the quantity of managerial and professional workers, $\Delta L n T e c h$ is the change in the quantity of technical and associated professional workers, Outp is the real gross output value and Wagepro and Wagetec is the real monthly wage rate of professional workers and technical workers, respectively. In addition, $i$ is the number of subsectors, $t$ is the year, $j$ is the category of labour, and $\varepsilon$ is the error term. All variables are indicated in the natural logarithm $(L n)$.

The ARDL model in this study uses a dynamic panel data as to analyse the short-run and long-run effects of determinants of labour demand (Pesaran \& Shin, 1995), Pesaran et al., 1996b). The model has two approaches, the mean group (MG) and pooled mean group (PMG). Both approaches allow for the shortrun and long-run analysis of labour demand, which becomes one of the focuses of this study.

$$
\begin{aligned}
& \operatorname{lnProf}_{i t}=\alpha_{0}+\delta_{11} \text { lnOutp }_{i t}+\delta_{12} \text { lnWagepro }_{i t}+\delta_{13} \text { lnWagete }_{i t}+\varepsilon_{1 t} \\
& \text { lnTech }_{i t}=\alpha_{1}+\delta_{21} \text { lnOutp }_{i t}+\delta_{22} \text { lnWagepro }_{i t}+\delta_{23} \text { lnWagetec }_{i t}+\varepsilon_{2 t}
\end{aligned}
$$




\section{Estimation of Manpower}

The estimation of manpower required for the construction sector draws attention as skilled labour is absolutely important to ensure that there is an adequate skilled workforce for the sector. In this analysis, the elasticity of labouroutput is used further to estimate the size of the labour workforce. This method is widely used to estimate the number of labour needed based on the output growth target (Abegaz, 1994). The estimation has an advantage as it can identify changes and trends in employment structures as a result of changes in technology and the environment (Huges, 1991).

As shown in equation (11), labour is estimated based on the annual output growth. Assuming the output is a continuous exponential growth, the yearly output growth rates from 2009 to 2012 were computed as shown below:

$$
\begin{aligned}
& Q_{t}=Q_{0} e^{r t} \\
& r t=\ln \left(Q_{t} / Q_{0}\right) \\
& r=\frac{1}{t} \ln \left(Q_{t} / Q_{0}\right)
\end{aligned}
$$

Where $Q_{t}$ is the output value of the terminal year, $Q_{0}$ is the output value of the initial year, $e$ is the exponential value $(\mathrm{e}=2.718), r$ is the growth rate, and $t$ is time or years. If the value of $\mathrm{r}>$ 0 , it denotes that the growth is increasing, and conversely if $r<0$, it is decreasing. Employing the annual output growth computed for this method, and labour elasticity taken from the SUR results of each group of labour according to each subsector, the estimation process is obtained from equation (12):

$$
L_{i j_{t}}=L_{i j_{0}}+\left(L_{i j_{0}} * n * \beta_{i j} * g_{r}\right)
$$

Where, $L_{i j}$ is the projected labour, $L_{i j_{0}}$ is the initial number of labour, $\beta_{i j}$ is labour demand elasticity, $n$ is number of year to be projected, $g_{\mathrm{r}}$ is the annual output growth rate, $i$ is the subsector under the construction sector, and $j$ is the type of labour. The absolute outcomes of the analysis are the estimation of the manpower in each skill type (professional and technical) according to subsectors.

\section{Findings and Discussion}

\section{Panel Unit Root Test}

The Autoregressive Distributed Lag (ARDL) co-integration technique, or bound test of cointegration (Pesaran \& Shin 1999; Pesaran et $a l ., 2001)$, is considered as a solution to verify the long-run relationship among variables that are non-stationary, as to re-parameterise them to the error correction model (ECM). The process of re-parameterisation is possible since the ARDL is a dynamic single model equation and has a similar form to the ECM. The distributed lag model basically indicates the inclusion of unrestricted lag of the regressors in a regression function (Nkoro \& Uko, 2016). The results provide a short-run dynamics (i.e. conventional ARDL) and a long-run relationship of the variables of a single model.

In addition, Pesaran et al. (1996b) proposed the ARDL approach to co-integration or bound procedure for a long-run relationship, irrespective of whether the underlying variables are at level $\mathrm{I}(0)$, at first difference $\mathrm{I}(1)$ or a combination of both. For this study, the Levin, Lin and Chu (LLC), and Im, Pesaran and Shin (IPS) stationary tests are employed (Levin, Lin \& Chu 2002; Im, Pesaran \& Shin, 2003). Table 1 shows the results of the unit root test for both procedures. Results from the LLC test show that all variables with and without trends are stationary at level I(0), at first difference I(1) and combination of both for the IMP test. In such a situation, the application of the ARDL approach to co-integration would give a consistent and efficient estimate, and this later indicates that the data used in this study are fit with the model estimation. 
Table 1: Results of the unit root test

\begin{tabular}{|c|c|c|c|c|}
\hline \multirow[b]{3}{*}{ Variables } & \multicolumn{4}{|c|}{ Levin, Lin \& Chu (LLC) } \\
\hline & \multicolumn{2}{|c|}{ Level } & \multicolumn{2}{|c|}{$1^{\text {st }}$ difference } \\
\hline & without trend & with trend & without trend & with trend \\
\hline $\ln$ Prof & $-2.347 * * *$ & $-3.389 * * *$ & $-6.712 * * *$ & $-5.632 * * *$ \\
\hline $\operatorname{lnTech}$ & $-3.731 * * *$ & $-2.923 * * *$ & $-6.228 * * *$ & $-6.274 * * *$ \\
\hline InWagepro & $-2.598 * * *$ & $-3.346^{* * *}$ & $-6.781 * * *$ & $-5.983 * * *$ \\
\hline lnWagetec & $-3.789 * * *$ & $-3.209^{* * *}$ & $-6.578 * * *$ & $-6.136^{* * *}$ \\
\hline \multirow[t]{3}{*}{ lnOutp } & $-2.298 * *$ & $-1.289 *$ & $-5.181 * * *$ & $-5.036 * * *$ \\
\hline & \multicolumn{4}{|c|}{ Im, Pesaran \& Shin (IPS) } \\
\hline & \multicolumn{2}{|c|}{ Level } & \multicolumn{2}{|c|}{$1^{\text {st }}$ difference } \\
\hline Variables & without trend & with trend & without trend & with trend \\
\hline $\ln$ Prof & -1.056 & $-1.816^{* *}$ & $-5.597 * * *$ & $-4.313 * * *$ \\
\hline $\operatorname{lnTech}$ & $-2.256^{* *}$ & -0.477 & $-5.028 * * *$ & $-4.796 * * *$ \\
\hline InWagepro & $-1.518^{*}$ & $-1.818^{* *}$ & $-5.543 * * *$ & $-4.467 * * *$ \\
\hline lnWagetec & $-2.058 * *$ & $-1.304 *$ & $-5.496 * * *$ & $-4.850 * * *$ \\
\hline $\operatorname{lnOutp}$ & -0.834 & $-1.771 * *$ & $-4.650 * * *$ & $-3.587 * * *$ \\
\hline
\end{tabular}

Notes: $*$ significant at $10 \%, * *$ significant at $5 \%, * * *$ significant at $1 \%$.

\section{Results of ARDL}

Table 2 shows the results of dynamic labour demand model by skill levels. The selection between pool mean group (PMG) and mean group (MG) is made based on the Hausman test. Under the null hypothesis, the Chisquare values are not significant both for professional and technical workers. This indicates that the PMG is a consistent and efficient estimation compared with MG, and therefore, the results of the analysis will be based on the PMG estimator.

From the table, the findings show that the absolute values of ECT for each category of skilled labour are less than one and it is significant at 0.1 and 0.05 levels of significance. This indicates the short-run and long-run relationships exist between the dependent and exogenous variables. The study discovers that in the short-run period, all exogenous variables are significant and have positive relationships with the demand for professional workers. The output variable indicates that it is consistent with the theory, which suggests that an increase in output will lead to an increase in demand for labour. Nonetheless, the effect of professional wage is not in line with the theory. The positive relationship between demand for professional workers and its own wage indicates a shortage of this category of labour in the construction sector.

In addition, the wage rate of technical workers also exhibits a positive impact on the demand for professional workers. This suggests substitubility between these two categories of labours. Such relationship is continued in the long run, except for the negative impact of professional wage rate, which shows that during a longer period, labour supply for professional workers will change and continue with the normal relationship. Intuitively, the findings show that in the long run, demand for professional labour is determined by its own wage, which is consistent with the labour demand theory.

The study also found that the output elasticity for the professional group is larger in the long run. An increase of $1 \%$ in the output will increase the labour demand for this group by $0.7062 \%$ and $1.3491 \%$ in the short and long run, respectively. The elasticity of own wage 
Table 2: Results of the ARDL

\begin{tabular}{lrr}
\hline \multicolumn{1}{c}{ Variable } & $\begin{array}{r}\text { InProf (PMG) } \\
\text { ARDL }(0,0,1,4)\end{array}$ & $\begin{array}{r}\text { InTech (PMG) } \\
\text { ARDL }(1,3,1,1)\end{array}$ \\
\hline Short-run effects & & -0.2232 \\
lnOutp & 0.7062 & $(0.1567)$ \\
& $(0.0721)^{* * *}$ & -0.6199 \\
lnWagepro & 0.3185 & $(0.1779)^{* * *}$ \\
& $(0.1377)^{* *}$ & 0.2404 \\
lnWagetec & 0.2811 & $(0.3486)$ \\
& $(0.0988)^{*}$ & -4.6355 \\
Constant & -4.1116 & $(2.1689)$ \\
& $(1.8597)^{* *}$ & -0.4968 \\
Error correction term (ECT) & -0.2861 & $(0.2258)^{* *}$ \\
\hline Long-run effects & $(0.1278)^{*}$ & 1.4833 \\
lnOutp & & $(0.1351)^{* * *}$ \\
lnWagepro & $(0.1416)^{* * *}$ & 0.3744 \\
& -2.8271 & $(0.1227)^{*}$ \\
lnWagetec & $(0.9914)^{* *}$ & -1.4627 \\
& 3.3107 & $(0.3732)^{* * *}$ \\
\hline Hausman Test (PMG or MG) & $(1.5067)^{*}$ & 0.24 \\
& 2.54 & $\left(\right.$ Prob $>$ chi $\left.^{2}=0.97\right)$ \\
\hline
\end{tabular}

Notes: $*$ significant at $10 \%, * *$ significant at $5 \%$ and $* * *$ significant at $1 \%$. Figures in bracket are standard deviation.

rate (professional group) is lower in the short run, even though the magnitudes are different. The shift in wage rate effect on the demand for labour in the short run is likely more stable. The findings show that an increase of $1 \%$ in wage rate will lower demand for professional labour by $2.8271 \%$ in the long run, but expand by $0.3185 \%$ in the short run.

Furthermore, in the long run, professional workers are supposed to be a replacement for technical workers as shown by the positive coefficient of the wage rate for professional workers. This situation is perhaps due to the skills enhancement of technical workers in long run via training and experience, which enable them to catch up with the skills owned by professional workers. The own wage rate for technical workers is negatively significant and this suggests a reduction in demand for this type of labour when its wages rises. A positive impact of the output on the demand for technical labour is also observed, whereby an increase of $1 \%$ in the output will increase the demand for technical workers by $1.4833 \%$.

Nevertheless, in the case of short runs, the findings on technical workers have less significant variables, but all variables are significant in the case of long runs. The only significant variable is the professional wage rate, which signifies a negative effect. This implies a complementarity relationship between these two types of workers in the short run. An increase of $1 \%$ in the professional wage rate will lower demand for technical workers by $0.6199 \%$.

\section{Results of SUR}

The results of labour demand estimates from the Seemingly Unrelated regression (SUR) are shown in Table 3 . The $\mathrm{R}^{2}$ values for professional and technical labour are approximately at 0.8629 and 0.8592 , meaning that $89.29 \%$ and $85.92 \%$ variations of each dependent variable 
Table 3: Results of the SUR

\begin{tabular}{lrr}
\hline Variable & InProf & InTech \\
\hline lnOutp & 1.1204 & 1.1895 \\
& $(0.05975)^{* * *}$ & $(0.06195)^{* * *}$ \\
lnWagepro & -1.0048 & -0.1225 \\
& $(0.1181)^{* * *}$ & $(0.1225)$ \\
lnWagetec & 0.2037 & -0.5192 \\
& $(0.2459)$ & $(0.2550)^{* *}$ \\
Constant & -4.3793 & -6.9713 \\
& $(0.8783)^{* * *}$ & $(0.9107)^{* * *}$ \\
\hline$R^{2}$ & 0.8629 & 0.8592 \\
Chi ${ }^{2}$ & 579.18 & 561.26 \\
p-value & $0.000^{* * *}$ & $0.000^{* * *}$ \\
Number of observation & 92 & 92 \\
\hline Breuch Pagan Chi ${ }^{2}$ & & \\
p-value & 5.871 & \\
\hline
\end{tabular}

Note: * significant at $10 \%, * *$ significant at $5 \%, * * *$ significant at $1 \%$, Figures in bracket are standard deviation.

could be explained by the determinant variables, respectively. The Chi-square value estimates for professional and technical workers of the whole construction sector are significant at a $1 \%$ level of significance. This shows that there are significant relationships between the dependent variables of each estimation with variations in the exogenous variables. The Chi-square value of the Breusch-Pagan test is also significant, which exhibits the effect of one group on another group of occupational categories and specified that the SUR are better estimates.

The findings reconfirm that the influences of wage rate and output are still consistent with the labour demand theory. The output is also performing a positive and significant role in determining demand for labour for the two categories of occupation. Meanwhile, the wage rate influences demand for labour for both occupational categories negatively and significantly. However, the cross-wage elasticity is not significant for both categories.

Table 4 presents the results on the estimation of the labour demand model for the professional and technical labour for each construction subsector. The value of $\mathrm{R}^{2}$ is more than 0.8 , showing that more than $80 \%$ of the variations in the dependent variable is explained by the independent variables in the model. The value of Chi-square and Breusch-Pagan Chi-square are significant for all subsectors, which reflects the appropriateness of the SUR estimation.

The influence of output on labour demand for both categories of labour and for all subsectors are positive and significant. The own wage elasticity for professional workers are all negative and significant for all subsectors, except for specialised construction activities. However, most of the own wage ealsticity for technical workers are not statistically significant, except for residential buildings, which is positively significant. For cross-wage elasticity, estimation results show that technical and professional labour are substituted in the residential building and civil engineering subsectors.

The elasticity of labour-output is very high and some of them approach unity, like in the professional business sector. An increase of $1 \%$ in the output value will increase demand for professional labour by $1.284 \%$ for the residential building subsector, $1.054 \%$ (nonresidential building), $1.005 \%$ (civil engineering) and $1.375 \% \quad$ (specialized construction activities). A similar trend is obtained for 
technical workers, with an increase of $1 \%$ in the output value resulting in $1.256 \%, 1.035 \%$, $1.007 \%$ and $1.490 \%$ increase in their demand for the subsectors of residential building, nonresidential building, civil engineering and specialised construction activities, respectively.

In terms of wage elasticity, there are sectors that recorded elasticity values exceeding unity. For instance, in the residential building subsector, a $1 \%$ increase in wage rate of professional workers will reduce demand for professional labour by $1.681 \%$, while a $1 \%$ increase in wage rate of technical workers decreases the demand for this category of labour by $1.214 \%$. Another subsector that shows high own wage elasticity for professional workers is civil engineering, with a value of -1.049 . The cross-wage elasticity is positive for professional workers in the residential building and civil engineering subsectors, implying the substitubility between technical and professional workers.

\section{Results of Manpower}

The annual output growth rates ranged from $6 \%$ to $10 \%$ for all subsectors for the period of 2009 to 2012, with the non-residential building subsector recording a higher growth of $10 \%$. However, the civil engineering subsector experienced the lowest annual growth rate. Between the periods of 2015 to 2020, the highest output growth rate for professional workers is exhibited by the non-residential building subsector at $6.9 \%$ and followed by the specialised construction activities subsector at $6.5 \%$. For the technical group, the specialised construction activities subsector experienced the highest output growth rate, followed by the non-residential building subsector.

Based on the output growth and labouroutput elasticity ${ }^{2}$, the number of manpower estimates for the four construction subsectors is presented in Table 5. In general, the labour demand for technical workers is relatively larger than that for professional workers. The manpower need for both categories of labour is dominated by the specialised construction activities subsector due to its larger initial labour stock and labour-output elasticity. It is followed by the residential building, non residential building and civil engineeering subsectors. The lenient government policy on property ownership and foreign ownership leads to the fast growth of this subsector.

\section{Conclusion}

From the analyses, this study has reached a few conclusions. Firstly, the results from the ARDL model conclude the relationships between the labour demand for professional workers, technical workers and its determinant exist in the short and long runs. Secondly, the supply of professional workers is still lacking, and this shortage is addressed through the substitution of technical workers. Thirdly, the results from the SUR model indicate that output is the most significant determinant affecting labour demand for the construction sector. The wage level has a negative relationship with demand for labour. The results are supported by the labour demand theory, but not in the case of the residential building subsector. This subsector continues in requiring large amount of workers with technical expertise and the challenge of obtaining this type of labour contributes to a positive influence of wages on technical labour demand. In addition, this study concludes that demand for technical and professional labour is complementary, specifically for the residential building and civil engineering subsectors.

Fourthly, the estimations for technical and professional labour show that the specialised construction activities subsector needs a large amount of workers. A large number of professional workers are intensely needed for the specialised construction activities subsector, while technical workers are essentially required for the non-residential building subsector, followed by the specialised construction activities subsector.

2 See Table 4. 


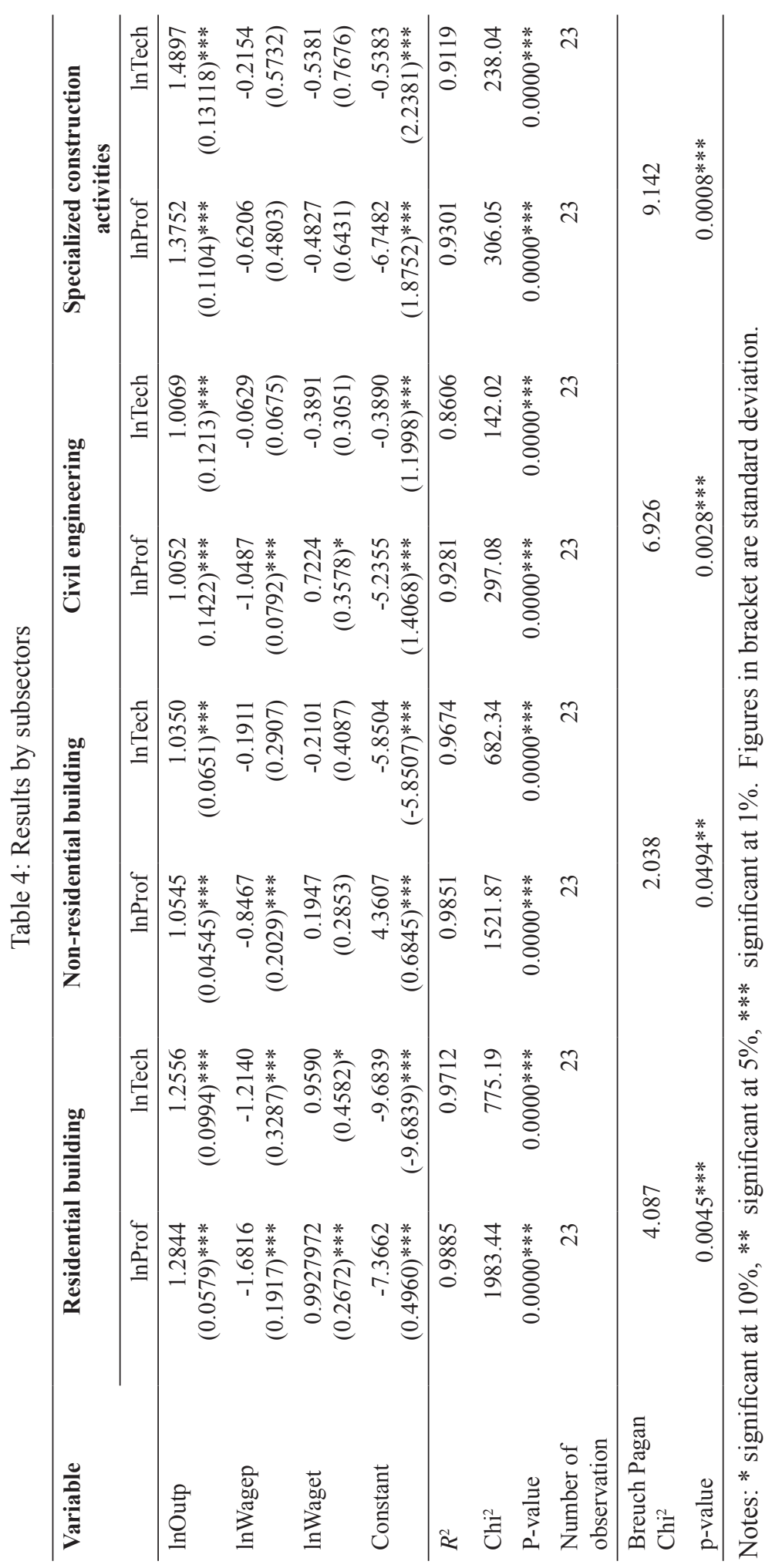

Journal of Sustainability Science and Management Volume 16 Number 4, June 2021: 236-252 
Table 5: Manpower estimates for 2015 and 2020

\begin{tabular}{|c|c|c|c|c|c|c|}
\hline Occupational category & Subsector & $2012\left(L_{i j o}\right)$ & $\beta_{1}$ & $g_{\mathrm{r}}$ & $n$ & $L_{i j t}$ \\
\hline & & & & & & 2015 \\
\hline \multirow[t]{4}{*}{ Professional } & 1 & 8010 & 1.28 & 0.07 & 3 & 10,163 \\
\hline & 2 & 9780 & 1.05 & 0.10 & 3 & 12,861 \\
\hline & 3 & 8640 & 1.01 & 0.06 & 3 & 10,202 \\
\hline & 4 & 10951 & 1.38 & 0.07 & 3 & 14,113 \\
\hline \multirow[t]{5}{*}{ Technical } & 1 & 9670 & 1.26 & 0.07 & 3 & 12,208 \\
\hline & 2 & 11159 & 1.04 & 0.10 & 3 & 14,607 \\
\hline & 3 & 9361 & 1.01 & 0.06 & 3 & 11,506 \\
\hline & 4 & 11522 & 1.49 & 0.07 & 3 & 15,127 \\
\hline & & & & & & 2020 \\
\hline \multirow[t]{4}{*}{ Professional } & 1 & 8010 & 1.28 & 0.07 & 8 & 13,752 \\
\hline & 2 & 9780 & 1.05 & 0.10 & 8 & 17,995 \\
\hline & 3 & 8640 & 1.01 & 0.06 & 8 & 12,808 \\
\hline & 4 & 10951 & 1.38 & 0.07 & 8 & 19,383 \\
\hline \multirow[t]{4}{*}{ Technical } & 1 & 9670 & 1.26 & 0.07 & 8 & 16,439 \\
\hline & 2 & 11159 & 1.04 & 0.10 & 8 & 20,354 \\
\hline & 3 & 9361 & 1.01 & 0.06 & 8 & 13,881 \\
\hline & 4 & 11522 & 1.49 & 0.07 & 8 & 21,136 \\
\hline
\end{tabular}

Notes:

i. Calculation of annual output growth rate $\left(g_{\mathrm{r}}\right)$ based on the output data (for the year 2009 and 2012) use the following formula: $Q_{t}=Q_{0} e^{r t}, r t=\ln \left(Q_{t} / Q_{0}\right), r=\frac{1}{t} \ln \left(Q_{t} / Q_{0}\right)$.

ii. Projection of manpower requirement is obtained using this formula:

$L_{i j_{t}}=L_{i j_{0}}+\left(L_{i j_{0}} * n * \beta_{i j} * g_{\mathrm{r}}\right)$.

iii. Subsector 1 = residential building, $2=$ non-residential building, $3=$ civil engineering, $4=$ specialized construction activities.

The implication of these findings is that efforts to increase output is crucial since it will increase demand for labour, hence, reduce unemployment. The wage rate that helps improve the welfare of workers can still be increased since it will increase demand for labour, especially for technical workers. Besides, the encouraging growth of demand for these two types of labour implies that present efforts of education and training need to be continued. A sufficient supply of labour is vital for a sustainable construction sector and this could be achieved through human development by enhancing health, knowledge, skills and awareness, increasing human capital and broadening opportunities and choices (UNDP, 2015).

Though the construction industry in Malaysia is labour-intensive, this industry is facing a shortage of labour, especially skilled labour. Therefore, skilled labour is essential in ensuring the sustainability of the construction sector, and specifically for its subsectors, as well as to achieve higher output and productivity. As this study focuses on the demand side of the labour market, it recommended that future research study the labour supply side. Such study will perhaps be able to fill in the gap of 
the research analysis, especially for high-skill workforce in the construction sector.

\section{Acknowledgements}

This study acknowledges the funding support from Universiti Kebangsaan Malaysia (UKM) for the Grant AP-2013-012.

\section{References}

Abegaz, B. (1994). Manpower development planning, theory and an African case studies. England: Ashgate Publishing Limited.

Adam, A., \& T., Moutos. (2014). Industrylevel labour demandeElasticities across the eurozone: Will there be any gain after the pain of internal devaluation? Working Paper 185, Bank of Greece.

Akintoye, A., \& Skitmore, M. R. (1994). Models of UK private sector quarterly construction demand. Construction Management and Economics, 12(1), 3-13.

Arnold, F., \& Shah, N. M. (2019). Asia’s labor pipeline: An overview. In Arnold, F., \& Shah, N. M. (Eds.), Asian labor migration: Pipeline to the middle east. New York: Routledge.

Behar, A. (2010). Would cheaper capital replace labour?. South African Journal of Economics, 78(2), 131-51.

Bhorat, H., Goya, S., \& Stanwix, B. (2013). Changing dynamics in the global labour market: Evidence from South Africa. International Labour Organization. Geneva.

Borjas, G. J. (2004). Does immigration grease the wheels of the labor market?, Brookings Papers on Economic Activity, 1, 69-119.

Chang-Richards, Y., Wilkinson, S., Seville, E., \& Brunsdon, D. (2017). Effects of a major disaster on skills shortages in the construction industry: Lessons learned from New Zealand. Engineering, Construction and Architectural Management, 24(1), $2-20$.
Chung, S. H., Jung, D. C., Yoon, S. N., \& Lee, D. (2010). A dynamic forecasting model for nursing manpower requirements in the medical service industry, Service Business, 4(3), 225-236.

Constant, A. F. (2014). Do migrants take the jobs of native workers? IZA World of Labor, 2014, 10.

Construction Industry Development Board Malaysia, CIDB. (2017). Country report Malaysia. Kuala Lumpur. Malaysia.

Construction Industry Development Board Malaysia, CIDB. (2018). Construction industries review and prospect 2018/2019. Kuala Lumpur. Malaysia.

Department of Statistics Malaysia (DoSM). (2012). Construction industry survey report. Kuala Lumpur: National Publication.

Department of Statistics Malaysia (DoSM). (2019). Annual economic statistics 2018: Construction sector. Putrajaya: Department of Statistics Malaysia.

Department of Statistics Malaysia (DoSM). (2020). Quarterly construction statistics. First quarter 2020. Putrajaya: Department of Statistics Malaysia.

Devesh, R. ., (2019). The micro elasticity of substitution and nonneutral technology. The RAND Journal of Economics, 50(1), 1-21.

Falk, M., \& Koebel, B. M. (2001). A dynamic heterogeneous labour demand model for German manufacturing, Applied Economics, 33(3), 339-348.

Huges, G. (1991). Manpower forecasting: Review of methods and practice in some OECD countries. Dublin: Longmano.

Im, K. S., M. H. Pesaran, \& Y. Shin. (2003). Testing for unit roots in heterogeneous panels. Journal of Econometrics, 115(1), 53-74.

Ismail, R., Yussof, I., \& Udin, N. (2012). Analysis of labour requirements in the Malaysian services sector, International 
Journal of Business and Management Science, 5(1), 19-37.

Ismail, R., Hui, P. L., \& Saukani, N. (2017). Forecasting of foreign labor demand in Malaysia's construction sector. Actual Problems of Economics, 6(192), 66-175.

Johansen, S., \& K. Juselius. (1990). Maximum likelihood estimation and inference on cointegration-with applications to the demand for money. Oxford Bulletin of Economics and Statistics, 52(2), 169-210.

Kim, K., \& G. J. D. Hewings. (2018). Bayesian estimation of labor demand by age: Theoretical consistency and an application to an Input-Output Model. Economic Systems Research, 31(1), 44-69.

Kreuser, C. F., \& Rankin, N. A. (2017). Capital and labour substitutability in South Africa. Research Project on Employment, Income Distribution and Inclusive Growth REDI3x3 Working Paper 36.

Labour Force Survey. (2011-2018). Labour Force Survey Report, Department of Statistics Malaysia, Putrayjaya.

Lelchumanan, B., Ismail, R., \& Sulaiman, N. (2019). Manpower requirements for selected services subsectors in Malaysia: An Input-Output Analysis. International Journal of Economics and Management, 13(1), 179-191.

Levin, A., C.-F. Lin, \& C.-S. J. Chu. (2002). Unit Root Tests in panel data: Asymptotic and finite-sample properties. Journal of Econometrics, 108(1), 1-24.

Luis, E. A., Castellani, F., \& Obando, N. (2019). Heterogeneous labour demand in the Colombian manufacturing sector. Journal for Labour Market Research, 53(1), 2-19.

Malaysia Productivity Corporation, MPC. (2017). Productivity Report 2016/2017. Malaysia Productivity Corporation. Petaling Jaya, Selangor. Malaysia.

Manap, N., Noh. M. N. H., \& Syahrom. (2017). Recruitment criteria and attraction strategies for local trained labour in Malaysia's construction industry. The International Conference on Eco Engineering Development 2017.

Manuel, F., \& Julián, M. (2018). Skill premium, labor supply, and changes in the structure of wages in Latin America. Journal of Development Economics, 135(C), 555-573.

Malaysia Standard Classification of Occupations (MASCO). (2008). Department of Statistics Malaysia, Putrajaya.

Mayer, J. (2000). Globalization, technology transfer and skill accumulation in lowincome countries. WIDER Project, No. 150. Geneva, UNCTAD.

Ministry of Finance Malaysia (MoF). (2018). Economic report 2016/2017. Kuala Lumpur: Percetakan Nasional Malaysia Berhad.

McGrath, S., \& Powell, L. (2016). Skills for sustainable development: Transforming vocational education and training beyond 2015. International Journal of Educational Development, 50(September), 12-19.

McKinsey \& Company. (2009). Accessed on the 24 August 2020,from https:// www.mckinsey.com/ /media/mckinsey/ dotcom/client_service/sustainability/cost/ pathways_lowcarbon_economy_version 2 . ashx.

(2019). Economic report 2017/2018. Kuala Lumpur: Percetakan Nasional Malaysia Berhad.

Mollick, A. V. (2011). The world elasticity of labor substitution across education levels. Empirical Economics, 41(3), 769-785.

Najib, M. I. S., Nordin, M. R., Ahnuar, M. E., \& Sukor, M. K. (2019). Malaysian as the component of labour force for construction industry in Malaysia. MATEC Web of Conferences.

Nkoro, E., \& Uko, A. K. (2016). Autoregressive Distributed Lag (ARDL) Cointegration Technique: Application and interpretation. 
Journal of Statistical and Econometric Methods, 5(3), 63-91.

O’Connor, D., \& M. R., Lunati. (1999). Economic opening and the demand for skills in developing countries: A review of theory and evidence. OECD Technical Paper No. 149, OECD, Paris.

Pesaran, M. H., \& Shin, Y. (1995). An Autoregressive Distributed Lag Modelling Approach to Co-Integration Analysis. Cambridge Working Papers in Economics 9514, Faculty of Economics, University of Cambridge.

Pesaran, M. H., R. J. Smith, \& Y. Shin. (1996b). Testing for the existence of a long run relationship. DAE Working Paper No.9622, Department of Applied Economics, University of Cambridge.

Pesaran, M. H, Yongcheol Shin \& Ron P. Smith. (1999). Pooled mean group estimation of dynamic heterogeneous panels. Journal of the American Statistical Association, 94(446), 621-634.

Rajapaksha, P. D. G., J. C. R. Smart, C. M. Fleming \& S. Hasan. (2018). The impact of climate change on labour demand in the plantation sector: The case of tea production in Sri Lanka. Australian Journal of Agricultural and Resource Economics, 62(3), 480-500.

Saens, R., Lobos, G., \& Rivera, E. (2008). Agricultural labor demand in Chile: A Cointegration Approach, Chilean Journal of Agricultural Research, 68(4), 391-400.

Sulaiman, N., Ismail R., \& Saukani, N. (2016). Labour demand elasticity and manpower requirements of skilled labour in Malaysian manufacturing sector. International Journal of Economic Research, 13(5), 2235-2250.

UNDP. (2015). Human development report 2015: Work for human development. New York: Oxford University Press.

Vendrik, M., \& Corvers, F. (2009). Male and female labour force participation: The role of dynamic adjustment to changes in labour demand, government policies and autonomous trends. IZA Discussion Paper No. 4397.

Wilson, R. A. (1994). Modelling and forecasting the structure of employment in the United Kingdom. London: Prentice Hall.

William, R. D. (2004). The demand for labour in the UK. National Statistics Feature. Labour Market Division, Office of National Statistics, United Kingdom, 321-330.

Wong, J., Chan, A., \& Chiang, Y. (2007). Forecasting construction manpower demand: A Vector Error Correction Model. Building and Environment, 42(8), 30303041 .

Wong, J., Chan, A., \& Chiang, Y. (2008). Modeling and forecasting construction labor demand: Multivariate analysis. Journal Construction Engineering and Management of American Society of Civil Engineering, 134(9), 664-672.

Zaki, A. S., Mohamed, F. S., \& Yusof, M. Z. (2012). Construction skilled labour shortage: The challenges in Malaysia construction sector. OIDA International Journal of Sustainable Development, 4(5), 99-108. 